\title{
Correlation and path analysis of biomass sorghum production
}

\author{
T.P.S. Vendruscolo ${ }^{1}$, M.A.A. Barelli ${ }^{2}$, M.A.S. Castrillon ${ }^{1}$, R.S. da Silva ${ }^{1}$, \\ F.T. de Oliveira ${ }^{1}$, C.L. Corrêa ${ }^{3}$, B.W. Zago ${ }^{4}$ and F.D. Tardin ${ }^{5}$ \\ ${ }^{1}$ Programa de Pós-Graduação em Genética e Melhoramento de Plantas, \\ Universidade do Estado de Mato Grosso, Cáceres, MT, Brasil \\ ${ }^{2}$ Departamento de Agronomia, Universidade do Estado de Mato Grosso, \\ Cáceres, MT, Brasil \\ ${ }^{3}$ Programa Nacional de Pós-Doutorado em Genética e Melhoramento de Plantas, \\ Universidade do Estado de Mato Grosso, Cáceres, MT, Brasil \\ ${ }^{4}$ Programa de Pós-Graduação em Rede de Biodiversidade e Biotecnologia da \\ Amazônia, Universidade do Estado de Mato Grosso, Cáceres, MT, Brasil \\ ${ }^{5}$ Núcleo de Recursos Genéticos e Obtenção de Cultivares, \\ Embrapa Milho e Sorgo, Sete Lagoas, MG, Brasil \\ Corresponding author: T.P.S. Vendruscolo \\ E-mail: taianapaula_abv@hotmail.com
}

Genet. Mol. Res. 15 (4): gmr15049086

Received August 17, 2016

Accepted November 11, 2016

Published December 23, 2016

DOI http://dx.doi.org/10.4238/gmr15049086

Copyright (C) 2016 The Authors. This is an open-access article distributed under the terms of the Creative Commons Attribution ShareAlike (CC BY-SA) 4.0 License.

\begin{abstract}
Sorghum biomass is an interesting raw material for bioenergy production due to its versatility, potential of being a renewable energy source, and low-cost of production. The objective of this study was to evaluate the genetic variability of biomass sorghum genotypes and to estimate genotypic, phenotypic, and environmental correlations, and direct and indirect effects of seven agronomic traits through path analysis. Thirty-four biomass sorghum genotypes and two forage sorghum genotypes were cultivated in a randomized block
\end{abstract}


design with three replicates. The following morpho-agronomic traits were evaluated: flowering date, stem diameter, number of stems, plant height, number of leaves, green mass production, and dry matter production. There were significant differences at the $1 \%$ level for all traits. The highest genotypic correlation was found between the traits green mass production and dry matter production. The path analysis demonstrated that green mass production and number of leaves can assist in the selection of dry matter production.

Key words: Biomass; Morpho-agronomic traits; Path analysis

\section{INTRODUCTION}

Researchers consider the use of plant residues or lignocellulosic biomass as one of the most promising energy sources for development nations. Therefore, in order to meet global demand, the future production of renewable and sustainable fuels will require the consistent and continuous production of biomass specifically for biofuels (Rocateli et al., 2012; Damasceno et al., 2013).

Several perennial energy crops have gained emphasis for bioenergy production using wood waste, forest residues, and eucalyptus wood. However, potential competition from food production crops is disadvantageous for perennial energy crops (corn and rice stover, elephant grass, sugarcane bagasse, brachiaria, sorghum, and others) because annual energy crops can be switched in the same agricultural area for both food production and energy (Peters and Thielmann, 2008; May, 2013a).

In this context, biomass sorghum [Sorghum bicolor (L.) Moench] is a promising alternative for the supply of raw material due to its versatility as a source of starch (second generation ethanol) and lignocellulose (bio-combustion). Other advantages include its short cycle (150-180 days), wide adaptability, seed propagation, fully mechanized production, and high productivity, which reaches $150 \mathrm{t} /$ ha of green mass (May, 2013b; Carrillo et al., 2013).

Studies on the biomass of sorghum crop remain scarce, especially regarding the characteristics that influence dry matter production. Thus, understanding correlations between traits is very important because it allows the breeder to understand changes that occur in a certain character based on the selection of others correlated to it. Thus, genetic improvement can improve the genetic material of the trait set (Ramalho et al., 1993).

The study of correlations leads to greater efficiency and reliability when combined with other analyses, such as path analysis. The path analysis, proposed by Wright (1921), identifies direct and indirect variables that are strongly correlated with the basic variable in order to obtain an efficient response. This analysis has been used in studies on various crops, such as saccharine sorghum (Lombardi et al., 2015), cotton (Hoogerheide et al., 2007; Farias et al., 2016), and soybean (Carvalho et al., 2002; Nogueira et al., 2012).

Based on the above considerations, the objectives of the present study were to evaluate the genetic variability of biomass sorghum genotypes and to estimate the genotypic, phenotypic, and environmental correlations, as well as the direct and indirect effects of seven agronomic traits through path analysis in order to select genotypes with greater dry matter production.

\section{MATERIAL AND METHODS}

The experiment was conducted in the year 2014/2015, from December to July, in

Genetics and Molecular Research 15 (4): gmr15049086 
the experimental area of the Genetic Resources \& Biotechnology Laboratory at Mato Grosso State University. The area is located at $16^{\circ} 11^{\prime} \mathrm{S}$ and $57^{\circ} 40^{\prime} \mathrm{W}$ at an average $118 \mathrm{~m}$ in altitude. The climate type according to the Köppen classification is Awa - mesothermal tropical, hot and humid, with dry winter. The annual mean temperature is $26^{\circ} \mathrm{C}$ and the annual rainfall is 1335 $\mathrm{mm}$, with a period of heavy rain from December to March (Neves et al., 2011).

The soil of the region was classified as Oxisol dystrophic (Couto et al., 2006). Soil was sampled from the $0-20-\mathrm{cm}$ layer, and the soil chemical characteristics used were: $\mathrm{pH}$ 5.4; $\mathrm{P}=4.7 \mathrm{mg} / \mathrm{dm} ; \mathrm{K}=77.1 \mathrm{cmol}_{\mathrm{c}} / \mathrm{dm} ; \mathrm{Ca}^{2+}=3 \mathrm{cmol}_{\mathrm{c}} / \mathrm{dm} ; \mathrm{Mg}^{2+}=0.8 \mathrm{cmol}_{\mathrm{c}} / \mathrm{dm} ; \mathrm{H}+\mathrm{Al}=2.3$ $\mathrm{cmol}_{\mathrm{c}} / \mathrm{dm}$; matéria orgânica do solo $=13.2 \mathrm{~g} / \mathrm{dm}$.

The experimental design used was a randomized block design with three replicates. Plots were composed of four 5-m lines, spaced $0.70 \mathrm{~m}$ apart, with a density of 10 plants per meter. Evaluations and data collection were performed in the two central rows, which were considered as the useful area.

The treatments consisted of 34 genotypes of biomass sorghum, all photoperiodsensitive hybrids (201429B001; 201429B002; 201429B003; 201429B004; 201429B005; 201429B006; 201429B007; 201429B008; 201429B009; 201429B010; 201429B011; 201429B012; 201429B013; 201429B014; 201429B015; 201429B016; 201429B017; 201429B018; 201429B019; 201429B020; 201429B021; 201429B022; 201429B023; 201429B024; 201429B025; 201429B026; 201429B027; 201429B028; 201429B029; 201429B030; 201429B031; 201429B032; 201429B033; BRS716) and two photoperiodinsensitive cultivars of forage sorghum, which were used as controls (Volumax and BRS655). All genotypes were from Embrapa Milho e Sorgo breeding program.

The planting was performed on December 5, 2014. To ensure row spacing was uniform, we used a seeder to demarcate the planting lines and sowed seeds by hand. The plots were fertilized at planting with $150 \mathrm{~kg} / \mathrm{ha}$ of the fertilizer 20/05/20 N-P $\mathrm{O}_{5}-\mathrm{K}_{2} \mathrm{O}$ and $375 \mathrm{~kg} /$ ha $\mathrm{P}_{2} \mathrm{O}_{5} ; 89 \mathrm{~kg} / \mathrm{ha}$ urea was applied as topdressing 45 and 80 days after planting. Weeds were controlled with the chemical herbicide Atriazine (3 L/ha), complemented by manual weeding.

Harvesting was performed manually, taking 10 plants per plot at an average 180 days after sowing. The morpho-agronomic traits evaluated were: flowering date (FLOR), stem diameter (SD), number of stems (NS), plant height (PH), number of leaves (NL), green mass production (GMP), and dry matter production (DMP) (Parrella, 2012).

The morpho-agronomic data were submitted to analysis of variance to verify the existence of variability among the 36 genotypes, and the means were compared by the Scott and Knott (1974) test at 5\% probability.

Phenotypic, genotypic, and environmental correlation coefficients were obtained using methods to estimate genetic correlations. The significance of phenotypic correlations was assessed using $t$-tests, and for the genetic and environmental correlations, the bootstrap procedure was used based on 5000 simulations to determine the significance and the strength of the correlations. Then, correlations were displayed for direct and indirect effects of characters with agronomic importance for sorghum (independent variables of the regression model) on the DMP (basic variable) through path analysis (Wright, 1921). All analyses were performed using the software Genes (Cruz, 2013).

\section{RESULTS AND DISCUSSIONS}

The genotypes of biomass sorghum differed significantly $(\mathrm{P}<0.01)$ for all traits,

Genetics and Molecular Research 15 (4): gmr15049086 
demonstrating that there is variability among their genetic constitution (Table 1). The results were similar to those obtained in other studies (Cunha and Lima, 2010; Tardin et al., 2013; Menezes et al., 2015; Silva et al., 2016). The experimental variation coefficients were normally distributed, demonstrating the accuracy of the experiment, which revealed low values for FLOR (0.59), SD (9.45), NS (4.36), PH (4.20), and NL (4.54), and medium values for GMP (16.09) and DMP (19.32) according to the classification proposed by Gomes (2009).

Table 1. Mean values for flowering (FLOR, days), stem diameter (SD, mm), number of stems (NS), plant height $(\mathrm{PH}, \mathrm{m})$, number of leaves $(\mathrm{NL})$, green mass production (GMP, $\mathrm{t} / \mathrm{ha})$, and dry matter production (DMP, t/ha) on the evaluation of biomass sorghum genotypes in Cáceres-MT in the 2014/2015 crop.

\begin{tabular}{|c|c|c|c|c|c|c|c|}
\hline GENOTYPES & FLOR & SD & NS & $\mathrm{PH}$ & NL & GMP & DMP \\
\hline 201429B001 & $135.33^{\mathrm{a}}$ & $22.02^{\mathrm{a}}$ & $19.80^{\mathrm{a}}$ & $5.34^{\mathrm{a}}$ & $20.06^{b}$ & $77.33^{\mathrm{a}}$ & $35.06^{\mathrm{a}}$ \\
\hline 201429B005 & $134.66^{\mathrm{a}}$ & $20.36^{\mathrm{a}}$ & $19.90^{\mathrm{a}}$ & $5.05^{\mathrm{b}}$ & $19.53^{\mathrm{b}}$ & $76.46^{\mathrm{a}}$ & $36.75^{\mathrm{a}}$ \\
\hline 201429B015 & $133.66^{\mathrm{a}}$ & $22.31^{\mathrm{a}}$ & $20.06^{\mathrm{a}}$ & $5.26^{\mathrm{a}}$ & $20.73^{b}$ & $75.66^{\mathrm{a}}$ & $37.67^{\mathrm{a}}$ \\
\hline 201429B008 & $133.66^{\mathrm{a}}$ & $20.82^{\mathrm{a}}$ & $19.10^{\mathrm{b}}$ & $5.01^{\mathrm{b}}$ & $19.50^{\mathrm{c}}$ & $75.56^{\mathrm{a}}$ & $32.18^{\mathrm{b}}$ \\
\hline 201429B013 & $132.66^{\mathrm{b}}$ & $23.26^{\mathrm{a}}$ & $20.40^{\mathrm{a}}$ & $5.06^{\mathrm{b}}$ & $20.30^{\mathrm{b}}$ & $75.83^{\mathrm{a}}$ & $36.89^{\mathrm{a}}$ \\
\hline 201429B032 & $132.33^{\mathrm{b}}$ & $21.31^{\mathrm{a}}$ & $19.16^{\mathrm{b}}$ & $5.26^{\mathrm{a}}$ & $18.90^{\mathrm{c}}$ & $81.50^{\mathrm{a}}$ & $35.01^{\mathrm{a}}$ \\
\hline 201429B031 & $131.33^{\mathrm{b}}$ & $22.18^{\mathrm{a}}$ & $20.86^{\mathrm{a}}$ & $5.45^{\mathrm{a}}$ & $19.96^{\mathrm{b}}$ & $74.10^{\mathrm{a}}$ & $34.69^{\mathrm{a}}$ \\
\hline 201429B006 & $131.33^{\mathrm{b}}$ & $21.41^{\mathrm{a}}$ & $20.50^{\mathrm{a}}$ & $4.95^{\mathrm{c}}$ & $20.73^{\mathrm{b}}$ & $80.73^{\mathrm{a}}$ & $38.18^{\mathrm{a}}$ \\
\hline BRS 716 & $131.00^{\mathrm{b}}$ & $22.18^{\mathrm{a}}$ & $20.56^{\mathrm{a}}$ & $5.18^{\mathrm{b}}$ & $19.80^{\mathrm{b}}$ & $79.76^{\mathrm{a}}$ & $40.69^{\mathrm{a}}$ \\
\hline 201429B012 & $128.66^{\mathrm{c}}$ & $22.94^{\mathrm{a}}$ & $20.80^{\mathrm{a}}$ & $5.04^{\mathrm{b}}$ & $21.63^{\mathrm{a}}$ & $76.46^{\mathrm{a}}$ & $38.05^{\mathrm{a}}$ \\
\hline 201429B033 & $128.33^{\mathrm{c}}$ & $20.85^{\mathrm{a}}$ & $18.90^{\mathrm{b}}$ & $5.34^{\mathrm{a}}$ & $18.50^{\mathrm{c}}$ & $72.06^{\mathrm{a}}$ & $30.37^{b}$ \\
\hline 201429B026 & $127.33^{\mathrm{c}}$ & $19.71^{\mathrm{a}}$ & $20.00^{\mathrm{a}}$ & $5.13^{\mathrm{b}}$ & $18.80^{\mathrm{c}}$ & $77.33^{\mathrm{a}}$ & $32.31^{\mathrm{b}}$ \\
\hline 201429B020 & $127.33^{\mathrm{c}}$ & $21.88^{\mathrm{a}}$ & $19.96^{\mathrm{a}}$ & $5.31^{\mathrm{a}}$ & $19.60^{\mathrm{b}}$ & $81.40^{\mathrm{a}}$ & $43.92^{\mathrm{a}}$ \\
\hline 201429B017 & $127.00^{\mathrm{c}}$ & $22.99^{\mathrm{a}}$ & $19.30^{\mathrm{b}}$ & $4.95^{\mathrm{c}}$ & $19.83^{b}$ & $67.33^{b}$ & $28.66^{\mathrm{b}}$ \\
\hline 201429B022 & $126.33^{\mathrm{c}}$ & $22.10^{\mathrm{a}}$ & $20.06^{\mathrm{a}}$ & $5.56^{\mathrm{a}}$ & $19.33^{\mathrm{c}}$ & $78.13^{\mathrm{a}}$ & $32.17^{\mathrm{b}}$ \\
\hline 201429B018 & $125.00^{\mathrm{d}}$ & $23.07^{\mathrm{a}}$ & $20.00^{\mathrm{a}}$ & $5.05^{\mathrm{b}}$ & $19.76^{\mathrm{b}}$ & $79.13^{\mathrm{a}}$ & $37.49^{\mathrm{a}}$ \\
\hline 201429B014 & $125.00^{\mathrm{d}}$ & $22.40^{\mathrm{a}}$ & $18.16^{\mathrm{b}}$ & $4.99^{\mathrm{b}}$ & $19.06^{\mathrm{c}}$ & $63.36^{\mathrm{b}}$ & $30.51^{\mathrm{b}}$ \\
\hline 201429B016 & $124.66^{\mathrm{d}}$ & $24.21^{\mathrm{a}}$ & $20.30^{\mathrm{a}}$ & $5.04^{\mathrm{b}}$ & $19.16^{\mathrm{c}}$ & $74.06^{\mathrm{a}}$ & $32.78^{\mathrm{b}}$ \\
\hline 201429B030 & $124.33^{\mathrm{d}}$ & $22.44^{\mathrm{a}}$ & $20.86^{\mathrm{a}}$ & $5.32^{\mathrm{a}}$ & $22.46^{\mathrm{a}}$ & $94.50^{\mathrm{a}}$ & $48.71^{\mathrm{a}}$ \\
\hline 201429B023 & $124.33^{\mathrm{d}}$ & $19.66^{\mathrm{a}}$ & $20.06^{\mathrm{a}}$ & $5.21^{\mathrm{b}}$ & $19.16^{\mathrm{c}}$ & $61.53^{\mathrm{b}}$ & $27.41^{\mathrm{b}}$ \\
\hline 201429B029 & $123.00^{\mathrm{d}}$ & $20.17^{\mathrm{a}}$ & $20.26^{\mathrm{a}}$ & $5.10^{\mathrm{b}}$ & $17.96^{\mathrm{c}}$ & $62.03^{\mathrm{b}}$ & $23.83^{\mathrm{b}}$ \\
\hline 201429B010 & $123.00^{\mathrm{d}}$ & $23.03^{\mathrm{a}}$ & $18.66^{\mathrm{b}}$ & $4.87^{\mathrm{c}}$ & $18.73^{\mathrm{c}}$ & $64.03^{\mathrm{b}}$ & $30.08^{b}$ \\
\hline 201429B002 & $123.00^{\mathrm{d}}$ & $21.83^{\mathrm{a}}$ & $17.70^{\mathrm{b}}$ & $5.06^{\mathrm{b}}$ & $18.73^{\mathrm{c}}$ & $70.23^{\mathrm{a}}$ & $32.27^{\mathrm{b}}$ \\
\hline 201429B009 & $122.00^{\mathrm{e}}$ & $22.32^{\mathrm{a}}$ & $18.63^{\mathrm{b}}$ & $4.78^{\mathrm{c}}$ & $18.96^{\mathrm{c}}$ & $78.30^{\mathrm{a}}$ & $37.64^{\mathrm{a}}$ \\
\hline 201429B003 & $121.33^{\mathrm{e}}$ & $22.00^{\mathrm{a}}$ & $17.93^{\mathrm{b}}$ & $4.76^{\mathrm{c}}$ & $18.73^{\mathrm{c}}$ & $71.73^{\mathrm{a}}$ & $30.80^{\mathrm{b}}$ \\
\hline 201429B004 & $121.00^{\mathrm{e}}$ & $23.29^{\mathrm{a}}$ & $17.70^{\mathrm{b}}$ & $4.74^{\mathrm{c}}$ & $18.56^{\mathrm{c}}$ & $72.80^{\mathrm{a}}$ & $31.00^{\mathrm{b}}$ \\
\hline 201429B007 & $120.00^{\mathrm{e}}$ & $21.02^{\mathrm{a}}$ & $17.53^{\mathrm{b}}$ & $4.67^{\mathrm{c}}$ & $18.66^{\mathrm{c}}$ & $57.09^{\mathrm{b}}$ & $27.44^{\mathrm{b}}$ \\
\hline 201429B011 & $119.66^{\mathrm{e}}$ & $20.65^{\mathrm{a}}$ & $18.43^{\mathrm{b}}$ & $4.51^{\mathrm{c}}$ & $18.13^{\mathrm{c}}$ & $50.86^{\mathrm{b}}$ & $22.83^{\mathrm{b}}$ \\
\hline 201429B027 & $119.33^{\mathrm{e}}$ & $20.14^{\mathrm{a}}$ & $18.70^{\mathrm{b}}$ & $5.18^{\mathrm{b}}$ & $17.66^{\mathrm{c}}$ & $62.13^{\mathrm{b}}$ & $23.61^{\mathrm{b}}$ \\
\hline 201429B019 & $119.33^{\mathrm{e}}$ & $24.07^{\mathrm{a}}$ & $17.80^{\mathrm{b}}$ & $4.52^{\mathrm{c}}$ & $19.13^{c}$ & $73.60^{\mathrm{a}}$ & $33.13^{b}$ \\
\hline 201429B021 & $116.00^{\mathrm{f}}$ & $23.51^{\mathrm{a}}$ & $19.93^{\mathrm{a}}$ & $5.04^{\mathrm{b}}$ & $17.33^{\mathrm{c}}$ & $78.06^{\mathrm{a}}$ & $31.52^{\mathrm{b}}$ \\
\hline 201429B025 & $115.00^{\mathrm{f}}$ & $19.78^{\mathrm{a}}$ & $18.86^{\mathrm{b}}$ & $5.14^{\mathrm{b}}$ & $19.30^{\mathrm{c}}$ & $57.09^{\mathrm{b}}$ & $25.88^{\mathrm{b}}$ \\
\hline 201429B024 & $113.00^{\mathrm{g}}$ & $22.76^{\mathrm{a}}$ & $18.80^{\mathrm{b}}$ & $4.86^{\mathrm{c}}$ & $18.63^{\mathrm{c}}$ & $68.96^{\mathrm{a}}$ & $32.07^{\mathrm{b}}$ \\
\hline 201429B028 & $110.00^{\mathrm{h}}$ & $21.65^{\mathrm{a}}$ & $18.56^{\mathrm{b}}$ & $4.95^{\mathrm{c}}$ & $18.30^{\mathrm{c}}$ & $57.63^{\mathrm{b}}$ & $24.39^{\mathrm{b}}$ \\
\hline Volumax & $84.00^{\mathrm{i}}$ & $13.96^{\mathrm{b}}$ & $13.86^{\mathrm{c}}$ & $3.27^{\mathrm{d}}$ & $15.83^{\mathrm{d}}$ & $62.08^{\mathrm{b}}$ & $22.00^{\mathrm{b}}$ \\
\hline BRS655 & $68.00^{j}$ & $13.56^{\mathrm{b}}$ & $11.60^{\mathrm{d}}$ & $2.54^{\mathrm{e}}$ & $13.20^{\mathrm{e}}$ & $48.28^{\mathrm{b}}$ & $17.51^{\mathrm{b}}$ \\
\hline Standard deviation & 0.64 & 2.25 & 1.30 & 9.55 & 1.54 & 9.70 & 6.39 \\
\hline
\end{tabular}

*Means followed by the same superscript letter in the column do not differ according to the Scott and Knott test at $5 \%$ probability.

These results showed that there was little influence of uncontrollable experimental variations, consistent with the values observed in previous studies. For example, Menezes et al. (2015), evaluated 49 sorghum hybrids for grain yield under water stress, and obtained coefficients of variation of $1.52 \%$ for flowering and $7.58 \%$ for plant height. Tardin et al. 
(2013) evaluated 49 sorghum hybrids grown under irrigation and water stress and obtained coefficients of variation of $1.24 \%$ for flowering and $8.05 \%$ for $\mathrm{PH}$.

Table 1 shows the mean values for morpho-agronomic traits evaluated by different genotypes and grouped by the Scott and Knott test at 5\% probability. The following values were obtained: FLOR 68-135.33 days; SD 13.56-24.21 mm; NS 11.60-20.86; PH 2.54-5.56 m; NL 13.20-22.46; GMP 48.28-94.50 t/ha, and DMP 17.51-48.71 t/ha.

The variable FLOR showed 10 groups of means. The forage sorghum hybrids Volumax and BRS655 were the earliest genotypes, flowering on average 76 days after planting. The biomass sorghum genotypes flowered approximately 110 days after planting, which confirms their photoperiod sensitivity since planting was performed in December under long days, and flowering began only in April when the days had a critical photoperiod. Parrella (2013) obtained similar flowering results in a study with 25 cultivars of biomass sorghum in four locations, where the average number of flowering days varied from 100 to 148 .

In order to evaluate the SD variable, 34 genotypes of biomass sorghum were allocated to a single group, leaving only two genotypes of forage sorghum isolated. For the NS variable, four groups were formed, in which the genotypes 201429B030, 201429B031, 201429B012, and BRS716 were those with the highest average values for NS. According to Perazzo et al. (2014) the traits SD and NS, represent the population of sorghum per unit area and can be associated with DMP.

The variables $\mathrm{PH}$ and $\mathrm{NL}$ allocated the sorghum genotypes into five groups for each. Regarding the $\mathrm{PH}$ variable, $63.88 \%$ of the sorghum genotypes were higher than $5 \mathrm{~m}$, ranging from 5.56 (genotype 201429B022) to $2.54 \mathrm{~m}$ (genotype control BRS655), and for NL, the widest mean variation was 22.46 leaves for the group with the greatest leaf production. According to Wight et al. (2012), PH and NL can be used as indicators of DMP in photoperiodsensitive sorghum genotypes, since they have a higher growing period, which contributes to increased growth and GMP.

The traits GMP and DMP allocated the genotypes into two groups each, for which the means ranged from 71.96 to $41.12 \mathrm{t} / \mathrm{ha}$ for the biomass genotypes and from 55.18 to $30.41 \mathrm{t} /$ ha for forage genotypes. Among the biomass sorghum genotypes, the individuals 201429B030 and 201429B020 are notable by the characteristic DMP as the two most productive genotypes, exceeding $40 \mathrm{t} / \mathrm{ha}$. However, these results are lower than those reported by Parrella et al. (2010), who evaluated 49 hybrids of biomass sorghum and obtained values of 57.87 and 53.13 t/ha dry matter production for the genotypes CMSX5651 and CMSX5652, respectively.

Estimates of the phenotypic $\left(\mathrm{r}_{\mathrm{F}}\right)$, genotypic $\left(\mathrm{r}_{\mathrm{G}}\right)$, and environmental $\left(\mathrm{r}_{\mathrm{E}}\right)$ correlation coefficients between pairs of characters were similar in terms of signal (except for one), direction, significance, and magnitude, ranging from 0.52 to $0.91 ; 0.47$ to 1.00 ; and $-0,067$ to 0.79 , respectively (Table 2 ).

In all cases, the genotypic correlation was higher than the phenotypic correlation, with the except of SD x GMP, which revealed that there was a greater contribution of genetic factors in the expression of these traits in relation to the environmental factor, being $95.23 \%$ significant by the bootstrap method at a $1 \%$ significance level. This prevalence was previously reported by Gonçalves et al. (1996) as a result of environmental modifying effects in association with the genetic characteristics. This demonstrates that the environment component had less of an influence than the genetic component on the expression of traits. According to Cruz and Regazzi (2001), genetic correlations involve a combination of inheritable factors, and can therefore be used in breeding programs.

Genetics and Molecular Research 15 (4): gmr15049086 
Table 2. Estimates of phenotypic $\left(\mathrm{r}_{\mathrm{F}}\right)$, genotypic $\left(\mathrm{r}_{\mathrm{G}}\right)$, and environment $\left(\mathrm{r}_{\mathrm{E}}\right)$ correlation coefficients for flowering (FLOR, days), stem diameter (SD, mm), number of stems (NS), plant height (PH, m), Number of leaves (NL), green mass production (GMP, t/ha), and dry matter production (DMP, t/ha).

\begin{tabular}{|c|c|c|c|c|c|c|c|}
\hline Traits & $r$ & SD & NS & $\mathrm{PH}$ & NL & GMP & DMP \\
\hline \multirow[t]{3}{*}{ FLOR } & $\mathrm{r}_{\mathrm{F}}$ & $0.73 * *$ & $0.88^{* *}$ & $0.90^{* *}$ & $0.83^{* *}$ & $0.59^{* *}$ & $0.63^{* *}$ \\
\hline & $r_{G}$ & $0.85^{++}$ & $0.91^{++}$ & $0.92^{++}$ & $0.87^{++}$ & $0.79^{++}$ & $0.75^{++}$ \\
\hline & $r_{E}$ & $0.28^{+}$ & 0.22 & -0.067 & 0.75 & $0.20^{+}$ & 0.21 \\
\hline \multirow[t]{3}{*}{ SD } & $\mathrm{r}_{\mathrm{F}}$ & & $0.70^{* *}$ & $0.70^{* *}$ & $0.68^{* *}$ & $0.52 * *$ & $0.58^{* *}$ \\
\hline & $\mathrm{r}_{\mathrm{G}}$ & & $0.81^{++}$ & $0.82^{++}$ & $0.81^{++}$ & $0.47^{+}$ & $0.58^{++}$ \\
\hline & $\mathrm{r}_{\mathrm{E}}$ & & $0.25^{+}$ & 0.11 & 0.14 & $0.63^{* *}$ & $0.57^{* *}$ \\
\hline \multirow[t]{3}{*}{ NS } & $\mathrm{r}_{\mathrm{F}}$ & & & $0.91 * *$ & $0.83^{* *}$ & $0.61 * *$ & $0.65^{* *}$ \\
\hline & $\mathrm{r}_{\mathrm{G}}$ & & & $0.94^{++}$ & $0.89^{++}$ & $0.78^{++}$ & $0.75^{++}$ \\
\hline & $r_{E}$ & & & $0.40^{*}$ & $0.22^{+}$ & $0.33^{*}$ & $0.34 *$ \\
\hline \multirow[t]{3}{*}{$\mathrm{PH}$} & $\mathrm{r}_{\mathrm{F}}$ & & & & $0.76^{* *}$ & $0.54 * *$ & $0.56^{* *}$ \\
\hline & $\mathrm{r}_{\mathrm{G}}$ & & & & $0.80^{++}$ & $0.68^{++}$ & $0.66^{++}$ \\
\hline & $r_{E}$ & & & & 0.19 & $0.39^{*}$ & 0.17 \\
\hline \multirow[t]{3}{*}{ NL } & $\mathrm{r}_{\mathrm{F}}$ & & & & & $0.67 * *$ & $0.79^{* *}$ \\
\hline & $\mathrm{r}_{\mathrm{G}}$ & & & & & $0.84^{++}$ & $0.92^{++}$ \\
\hline & $r_{E}$ & & & & & $0.41^{* *}$ & $0.42^{* *}$ \\
\hline \multirow[t]{3}{*}{ GMP } & $\mathrm{r}_{\mathrm{F}}$ & & & & & & $0.91 * *$ \\
\hline & $\mathrm{r}_{\mathrm{G}}$ & & & & & & $1.00^{++}$ \\
\hline & $\mathrm{r}_{\mathrm{E}}$ & & & & & & $0.79^{\text {** }}$ \\
\hline
\end{tabular}

**,*Significant at 1 and $5 \%$ probability by the $t$-test. ${ }^{+,+}$Significant at 1 and $5 \%$ probability by the bootstrap method based on 5000 simulations.

The environmental correlations were different in magnitude and sign in relation to the genotypic correlations. This reveals that the environment benefits one trait at the detriment of another, and the causes of genetic and environmental variation affect the characteristics via different physiological mechanisms (Falconer, 1987). As an example we can mention the correlation between FLOR and PH, which presented a high magnitude of genotype correlation (0.92), however the presence of negativity in the residual correlation sign $(-0.067)$ characterizes that the environment favoring the increase in $\mathrm{PH}$ disfavor the reduction at the beginning of flowering. The correlation between the pairs SD and GMP, and SD and DMP, which both showed higher environmental than genotype correlations, indicated there was an environmental influence on those traits.

Genotypic correlations of a moderate magnitude occurred between the pairs SD and GMP (0.47), PH and GMP (0.68), and PH and DMP (0.66), indicating that increases in SD and HD do not necessarily imply an increase in the production of GMP and DMP. However, the absence of negative signals indicates that it would be possible to gather, in future generations, plants with larger SD and GMP, as well as increases in PH and DMP.

Genotypic correlations of high magnitude were observed between GMP and DMP (1.00); NS and PH (0.94), FLOR and NS (0.91), FLOR and PH (0.92), and NL and DMP (0.92), and were associated with the superiority of genotypic over phenotypic correlations, allowing us to conclude that selection for these traits could produce, in future generations, plants with higher biomass production. These results are consistent with those obtained by Cunha and Lima (2010) in a study with 29 sorghum genotypes, in which a high positive genotypic correlation (0.83) was found between GMP and DMP. Perazzo et al. (2014), in a study with 32 sorghum cultivars in the Brazilian semiarid, also found positive and significant correlations between GMP and DMP (0.87).

The trait FLOR was strongly correlated with NS and PH, and a strong correlation was

Genetics and Molecular Research 15 (4): gmr15049086 
also observed with all other characters. This correlation is possibly due to the photoperiod sensitivity of this genotype, which provides an increase in the vegetative cycle and flowering, and consequently in the values for the remaining characters (SD, NS, PH, NL, GMP, and DMP). These results differ in part from those obtained by Castro (2014), who studied genotypes of biomass sorghum, and obtained weak correlations for FLOR x NS (0.30) and strong correlations for FLOR x DMP (0.83) and FLOR x PH (0.90).

In breeding programs, information on the correlations between characters is essential to improve the simultaneous selection of characters. However, measuring and interpreting the magnitude of a correlation can lead to mistakes in the selection strategy due to pleiotropism.

For these reasons, we proceeded to do a path analysis, which investigates the cause and effect of the relationships into direct and indirect effects of a group of traits over a basic or main variable (Cruz et al., 2004).

Estimates of direct and indirect effects of the independent variables FLOR, SD, NS, $\mathrm{NL}, \mathrm{PH}$, and GMP on the production of dry matter are shown in Table 3. The coefficient of determination $\left(\mathrm{R}^{2}\right)$ of the path analysis was $90.58 \%$, indicating that DMP can be explained by the effects of the analyzed traits. The residual effect of $30.69 \%$ reflects the contribution of the variables in the model to the basic variable. Therefore, the explanatory model used expressed the cause and effect relationship between the primary variables and the DMP.

GMP exhibited the strongest correlation with DMP (0.9123), and had a high direct effect (0.6933); therefore, genotypes with higher DMP can be obtained from the selection of plants with higher GMP. NL had a correlation of 0.7885 and was of high magnitude (0.4648), demonstrating the existence of a strong association between this trait and the basic variable.

Both the GMP and NL traits exhibited strong genotypic correlations with the basic variable DMP $\left(\mathrm{r}_{\mathrm{G}}=1.00, \mathrm{r}_{\mathrm{G}}=0.92\right)$, and indirect effects were also high for both traits. Therefore, these two variables can promote DMP in a simultaneous selection process. Çarpici et al. (2010) studied forage maize and found a positive and significant correlation between green leaves and DMP.

SD presented a low direct effect (0.0707) on DMP with a high magnitude (0.5844); therefore, this variable must be considered during indirect selection for DMP.

We observed negative direct effects and low magnitude for FLOR, NS, and PH (-0.0735, -0.0324 , and -0.1280 ), indicating the low contribution of these variables to the dry matter production the DMP. However, these traits were estimated to have high correlation estimates, which occurred in all cases by the indirect effects of GMP, NS, and SD, such as the NS correlation with DMP being primarily due to the indirect effects of GMP (0.4279) and NL (0.3872). According to Lorentz et al. (2006), when the correlation coefficient is positive, but the direct effect is negative or negligible, the relationship will be caused by indirect effects, which was observed in the present analysis. Similar results were obtained by Entringer et al. (2014), who used production components of super sweet corn and determined that only two of the eight variables had a direct effect on the basic variable, whereas the others occurred by an indirect effect.

Thus, it can be inferred that both direct and indirect selection of the GMP and NL traits are effective at increasing the DMP. In this case, the best strategy would involve the simultaneous selection of traits, emphasizing the characteristics for which direct effects are higher. Cruz and Regazzi (2001) indicated that, for breeding purposes, it is important to verify the traits that exhibit a high correlation with the main variable and those with the highest favorable direct effect to the selection, so that a correlated response using indirect selection is efficient.

Genetics and Molecular Research 15 (4): gmr15049086 
Table 3. Estimates of the direct and indirect effects of six morpho-agronomic traits on the main variable (dry matter production, DMP) obtained by the path analysis method.

\begin{tabular}{|c|c|c|}
\hline Trait $^{1}$ & Association & Estimate \\
\hline \multirow[t]{7}{*}{ FLOR } & Direct effect on DMP & -0.0735 \\
\hline & Indirect effect on GMP & 0.4101 \\
\hline & Indirect effect on SD & 0.0521 \\
\hline & Indirect effect on NS & -0.0286 \\
\hline & Indirect effect on $\mathrm{PH}$ & -0.1156 \\
\hline & Indirect effect on NL & 0.3863 \\
\hline & Total & 0.6308 \\
\hline \multirow[t]{7}{*}{ GMP } & Direct effect on DMP & 0.6933 \\
\hline & Indirect effect on FLOR & -0.0433 \\
\hline & Indirect effect on SD & 0.0370 \\
\hline & Indirect effect on NS & -0.0200 \\
\hline & Indirect effect on $\mathrm{PH}$ & -0.0702 \\
\hline & Indirect effect on NL & 0.3157 \\
\hline & Total & 0.9123 \\
\hline \multirow[t]{7}{*}{ SD } & Direct effect on DMP & 0.0707 \\
\hline & Indirect effect on FLOR & -0.0541 \\
\hline & Indirect effect on GMP & 0.3628 \\
\hline & Indirect effect on NS & -0.0229 \\
\hline & Indirect effect on $\mathrm{PH}$ & -0.0900 \\
\hline & Indirect effect on NL & 0.3179 \\
\hline & Total & 0.5844 \\
\hline \multirow[t]{7}{*}{ NS } & Direct effect on DMP & -0.0324 \\
\hline & Indirect effect on FLOR & -0.0650 \\
\hline & Indirect effect on GMP & 0.4299 \\
\hline & Indirect effect on SD & 0.0502 \\
\hline & Indirect effect on $\mathrm{PH}$ & -0.1168 \\
\hline & Indirect effect on NL & 0.4279 \\
\hline & Total & 0.6512 \\
\hline \multirow[t]{7}{*}{$\overline{\mathrm{PH}}$} & Direct effect on DMP & -0.1280 \\
\hline & Indirect effect on FLOR & -0.0663 \\
\hline & Indirect effect on GMP & 0.3805 \\
\hline & Indirect effect on SD & 0.0497 \\
\hline & Indirect effect on NS & -0.0295 \\
\hline & Indirect effect on NL & 0.3540 \\
\hline & Total & 0.5603 \\
\hline \multirow[t]{7}{*}{ NL } & Direct effect on DMP & 0.4648 \\
\hline & Indirect effect on FLOR & -0.0611 \\
\hline & Indirect effect on GMP & 0.4709 \\
\hline & Indirect effect on SD & 0.0484 \\
\hline & Indirect effect on NS & -0.0269 \\
\hline & Indirect effect on $\mathrm{PH}$ & -0.0975 \\
\hline & Total & 0.7885 \\
\hline \multicolumn{2}{|c|}{ Determination coefficient $\left(\mathrm{R}^{2}\right)$} & 0.9058 \\
\hline Residual variable $\left(\rho^{\wedge} \epsilon\right)$ & & 0.3069 \\
\hline
\end{tabular}

${ }^{1} \mathrm{FLOR}=$ number of days to flowering (days); GMP = green mass production $(\mathrm{t} / \mathrm{ha}) ; \mathrm{NL}=$ number of leaves; $\mathrm{NS}=$ average number of stems; $\mathrm{PH}=$ average plant height $(\mathrm{m}) ; \mathrm{SD}=$ average stem diameter $(\mathrm{mm})$.

\section{Conflicts of interest}

The authors declare no conflict of interest.

\section{ACKNOWLEDGMENTS}

The authors thank CNPq, EMBRAPA, and FAPEMAT for providing financial support 
Correlation and path analysis among agronomic traits of biomass sorghum

for this study (post-graduate), who promote incentives and technological support for research activities, and Embrapa Milho e Sorgo, Sete Lagoas, Minas Gerais, for providing technical support.

\section{REFERENCES}

Carrillo MA, Staggenborg SA and Pineda JA (2013). Washing sorghum biomass with water to improve its quality for combustion. Fuel 116: 427-431. http://dx.doi.org/10.1016/j.fuel.2013.08.028

Carvalho CGP, Arias CAA, Toledo JFF, Oliveira MF, et al. (2002). Correlações e análise de trilha em linhagens de soja semeadas em diferentes épocas. Pesq. Agropec. Bras. 37: 311-320. http://dx.doi.org/10.1590/S0100204X2002000300012

Castro FMR (2014). Potencial Agronômico e Energético de Híbridos de Sorgo Biomassa. Master's thesis, UFL, Lavras.

Çarpici EB, Çelik N and Bayram G (2010). Yield and quality of forage maize as influenced by plant density and nitrogen rate. Turk. J. Field Crops 15: 128-132.

Couto E, Higa NT, Azevedo EC. (2006). Sistema brasileiro de classificação de solos. Available at [http://www.infoteca. cnptia.embrapa.br/bitstream/doc/338818/1/sistemabrasileirodeclassificacaodossolos2006.pdf]. Accessed August 20, 2016.

Cruz CD (2013). GENES: a software package for analysis in experimental statistics and quantitative genetics. Acta Sci. Agron. 35: 271-276. http://dx.doi.org/10.4025/actasciagron.v35i3.21251

Cruz CD and Regazzi AJ (2001). Modelos biométricos aplicados ao melhoramento. 2nd edn. Universidade Federal de Viçosa, Viçosa.

Cruz CD, Regazzi AJ, Carneiro AJ and Souza PC (2004). Modelos biométricos aplicados ao melhoramento genético. UFV, Viçosa.

Cunha EE and Lima JMP (2010). Characterization of genotypes and estimates of genetic parameters of productive traits for forage sorghum. Rev. Bras. Zootec. 39: 701-706. http://dx.doi.org/10.1590/S1516-35982010000400002

Damasceno CM, Parrella RA da C, Souza VF, Simeone MLF, et al. (2013). Análise Morfoagronômica e Bioquímica de Um Painel de Sorgo Energia para Características Relacionadas à Qualidade da Biomassa. Embrapa Milho e Sorgo. Circular Técnica 190. Embrapa Milho e Sorgo, Sete Lagoas, 7.

Entringer GC, Santos PHAD, Vettorazzi JCF, Cunha KS, et al. (2014). Correlação e análise de trilha para componentes de produção de milho superdoce. Rev. Ceres 61: 356-361. http://dx.doi.org/10.1590/S0034-737X2014000300009

Falconer DS (1987). Introdução à genética quantitativa. 2st edn. Universidade Federal de Viçosa, Viçosa.

Farias FJC, Carvalho LP, Silva Filho JL and Teodoro PE (2016). Correlations and path analysis among agronomic and technological traits of upland cotton. Genet. Mol. Res. 15: 15038239. http://dx.doi.org/10.4238/gmr.15038239

Gomes FP (2009). Curso de estatística experimental. 15st edn. Fundação de Estudos Agrários Luiz de Queiroz, Piracicaba.

Gonçalves PS, Martins ALM, Bortoletto N and Tanzini MR (1996). Estimates of genetic parameters and correlations of juvenile character based on open pollinates progenies of Hevea. Braz. J. Genet 19: 105-111.

Hoogerheide ESS, Vencovsky FJCF, Freire EC and Arantes EM (2007). Correlações e análise de trilha de caracteres tecnológicos e a produtividade de fibra de algodão. Pesq. Agropec. Bras. 42: 1401-1405. http://dx.doi.org/10.1590/ $\underline{\text { S0100-204X2007001000005 }}$

Lombardi GMR, Nunes JAR, Parrella RA, Teixeira DHL, et al. (2015). Path analysis of agro-industrial traits in sweet sorghum. Genet. Mol. Res. 14: 16392-16402. http://dx.doi.org/10.4238/2015.December.9.8

Lorentz LH, Fortes FO and Lúcio AD (2006). Path analysis in seed analyzes of exotic forest species of Rio Grande do Sul. Rev. Tree. 30: 567-574.

May A (2013a). Cultivo do sorgo biomassa para a cogeração de energia Elétrica. Embrapa Milho e Sorgo, Documentos 152. Embrapa Milho e Sorgo, Sete Lagoas, 65.

May A (2013b). Cultivo de Sorgo Sacarino em Áreas de Reforma de Canaviais. EMBRAPA/CNPMS. Circular Técnica, Sete Lagoas, 36.

Menezes CB, Saldanha DC, Santos CV, Andrade LC, et al. (2015). Evaluation of grain yield in sorghum hybrids under water stress. Genet. Mol. Res. 14: 12675-12683. http://dx.doi.org/10.4238/2015.October.19.11

Neves SMAS, Nunes MCM and Neves RJ (2011). Caracterização das condições climáticas de Cáceres/MT Brasil, no período de 1971 a 2009: subsídio às atividades agropecuárias e turísticas municipais. Boletim Goiano Geográfico 31: 55-68.

Nogueira APO, Sediyama T, Sousa LB, Hamawaki OT, et al. (2012). Análise de trilha e correlações entre caracteres em soja cultivada em duas épocas de semeadura. Biosci. J. 28: 877-888.

Parrella RA da C (2013). Cultivo do Sorgo Biomassa para a Cogeração de Energia Elétrica. Embrapa Milho e Sorgo. Boletim de Pesquisa e Desenvolvimento 152. Embrapa Milho e Sorgo, Sete Lagoas, 69.

Genetics and Molecular Research 15 (4): gmr15049086 
Parrella RA da C, Rodrigues JAS, Tardin FD, Damasceno CMB, et al. (2010). Desenvolvimento de híbridos de sorgo sensíveis ao fotoperíodo visando alta produtividade de biomassa. Embrapa Milho e Sorgo, Boletim de Pesquisa e Desenvolvimento 28. Embrapa Milho e Sorgo, Sete Lagoas, 25.

Parrella RA da C, Parrella NNLD, Souza VF, Schaffert RE, et al. (2012). Desempenho agronômico e energético de híbridos de sorgo biomassa. In: Anais $29^{\circ}$ Congresso de Milho e Sorgo, Águas de Lindóia.

Peters J and Thielmann S (2008). Promoting biofuels: implications for developing countries. Energy Policy 36: 15381544. http://dx.doi.org/10.1016/j.enpol.2008.01.013

Perazzo AF, Carvalho GGP, Santos EM, Pinho RMA, et al. (2014). Agronomic evaluation of 32 sorghum cultivars in the Brazilian semi-arid region. Rev. Bras. Zootec. 43: 232-237. http://dx.doi.org/10.1590/S1516-35982014000500002

Ramalho MAP, Santos JB and Zimmermman MJO (1993). Genética quantitativa em plantas autógamas: aplicações ao melhoramento do feijoeiro. 1st edn. Universidade Federal de Goiânia, Goiânia.

Rocateli AC, Raper RL, Balkcom KS, Arriaga FJ, et al. (2012). Biomass sorghum production and components under different irrigation/tillage systems for the southeastern U.S. Ind. Crops Prod. 36: 589-598. http://dx.doi.org/10.1016/j. indcrop.2011.11.007

Scott AJ and Knott M (1974). A cluster analysis method for grouping eans in the analysis of variance. Biometric. 30: 507512. http://dx.doi.org/10.2307/2529204

Silva AL, Tardin FD, Rotta GW, Baldoni AB, et al. (2016). Characterization of biomass sorghum cultivars aiming to generate energy for the north region of Mato Grosso, Brazil. Nativa. 4: 175-178. http://dx.doi.org/10.14583/23187670.v04n03a11

Tardin FD, Almeida filho JE, Oliveira CIM, Leite CEP, et al. (2013). Avaliação agronômica de híbridos de sorgo granífero cultivados sob irrigação e estresse hídrico. Rev. Bras. Milho Sorgo 2: 102-117. http://dx.doi.org/10.18512/1980-6477/ rbms.v12n2p102-117

Wight JP, Hons FM, Storlien JO, Provin TL, et al. (2012). Management effects on bioenergy sorghum growth, yield and nutrient uptake. Genet. Mol. Res. 14: 593-604.

Wright S (1921). Correlation and causation. J. Agric. Res. 20: 557-585.

Genetics and Molecular Research 15 (4): gmr15049086 